\title{
The Issues \& Challenges of Diversity in Contemporary Pakistan: is Consociational Democracy a Viable Solution?
}

\author{
Samina Noor* \\ Islamia University Bahawalpur, \\ Pakistan
}

Received 12.11.2014, received in revised form 10.12.2014, accepted 21.01.2015

Pakistan now days facing many issues and challenges which pose threats to stability and democratization, and ethnicity one of them. In this research we analysis how ethnic diversity damages the roots of democracy in contemporary Pakistan. Does Pakistan need to implement and preserve Consociational theory to practice democracy? If therefore, what Consociational measures would be more likely to accommodate ethnic minorities? This research paper attempts to answer these questions looking thoroughly at the ethnic composition of Pakistan, the role and strength of the Pakistani Federation towards managing of diversity, and the measures of power sharing presented by Lijphart's Consociational democracy.

Keywords: Consociational democracy, power sharing, proportional representation, provincial autonomy.

Research area: politology.

\section{Inroduction}

Pakistan is multiethnic, multicultural and multilingual society like most of the developing countries in the world. From the very first day of its birth, the aspirations of the people of Pakistan to live in peace and harmony and to have a degree of material security have been unfulfilled. The relationship of ethnicity and political system of government is even more important in the social life of human beings because ethnicity is fundamentally a continuous, dynamic process that occurs between two or more ethnic populations.

Democracy is a form of government in which the people govern themselves or elect representatives to govern them. Most Asian democracies feature highly diverse societies divided along multiple cleavages of geography, language, history, class, and culture. Therefore, these countries are facing the problem of stable democracy.

Pakistani society it characterized by its multi-linguistic, multi-ethnic, and class-divided texture. Pakistan, these days are passing through a crucial era of multifarious ethnic problems multi-lingual and regional problems etc. Pakistan, since its creation, has facing several challenges to the immovability of its democratic system, which prerequisite for its growth. The political system

(C) Siberian Federal University. All rights reserved

* Corresponding author E-mail address: sameena.noor786@yahoo.com 
of Pakistan has been followed by the military rule after the least touch of democracy. These gradually transitions in the political system, makes it more vulnerable to both internal and external threats.

In order to accommodate group rights in ethnic diverse society's alternative to majority rule and to the concentration to the hand of the center have to be envisaged. Lijphart maintains that democracy is possible in deeply divided societies but only if their type of democracy is sensational. Certain European countries have managed diversity through consociationalism but the overall performance of such arrangements remains mixed. Subsequently, the consociationalists have recommended that Pakistan will need to adopt and maintain consociational governance at the federal center to practice democracy. In this paper we mainly focused on those factors which contribute to make Pakistan non-consociational democracy in the contemporary period.

\section{Ethnic cleavages in Pakistan}

Most of the countries in world created on multicultural and multinational basis. They have their independent cultural traits and world views. Such kind of plurality needs careful management and ethnic accommodation, especially because it leads to inevitable competition and often conflict between these disparate groups. The political systems in divers' countries are generally based on the favor of the majority ethnic group. In case of Pakistan, it is the Punjabis; this creates a feeling of insecurity among the minorities.

Language is an important tool for ethnic identity in highly diverse societies. In Pakistan there have been twenty spoken languages. Pakistani nation divided into following factions; Punjabi, Sindhi, and Urdu as well as Pakhtun or Pashto, Balochi. To analysis the ethnic conflicts in Pakistan, it is indispensable to have a revisit to the inception days of Pakistan. According to typical text books tells us how the creation of Pakistan has been done for the sake of Islam. Muhammad Ali Jinnah leads the nation to create a State which would be built on true Islamic ideology rather than secular ideology which was promoted by Congress. ${ }^{1}$

Unfortunately, Pakistan movement in British Subcontinent was very sturdy in the Muslim marginal areas; where Muslims feared Hindu domination most after the independence of Subcontinent. However, Pakistan was bent in the Muslim majority Provinces on ethnic, linguistic and cultural lines. Muhammad Ali Jinnah had trusted that the bond of Islamic Ideology would be wiped out all the metamorphoses among diverse groups. ${ }^{2}$

In early years, all top official and political positions rotated among Mohajirs, for they were highly profiled as compared to the other ethnic groups. Punjabi-Mohajir did not like much eastern Pakistan domination over political and economic spares of Pakistan. These differences had sparked the Urdu- Bangali language disparities among both wings of Pakistan. The language controversy which leads to the deprived feelings among the people of East Pakistan and the ultimate consequence was occurring in the form of separation of East Pakistan in 1971s. ${ }^{3}$

The constitutions of 1956 and 1962 did not fill the vacuum that grows larger and larger after every passing day, while the constitution of 1973 unsuccessful to ensure provincial autonomy, national integration and ethnic diversity. The least representation of Sindhies, Baluch and Pakhtun has created a strong sense of discrimination among their youth. Along with this, another important factor in the widening gap between ethnic groups is the military dictatorships, which further worsen the ethnic cleavages. 


\section{Consociational democracy in divided socities}

In third world especially in Asia Bangladesh, Thailand, Nepal, the Philippines, Pakistan, and Indonesia have all emerged from authoritarian, militaristic, and single party domination. Most third world countries have found democracies but with the feature of high divers societies divided along multiple cleavages of language, history, class, geography, and culture.

Democracy is difficult to maintain in societies that divided along deep ethnic cleavages. Elections in such divided societies will often encourage centrifugal politics that lead extremist ethnic appeals, zero-sum political attitude and ethnic conflicts, and at the end becomes the breakdown of democracy.

The decade of the 1960s saw a major debate among political scientists over the question of the stability of democracies in deeply divided societies. Arend Lijphart defines consociational democracy as a model with four characteristics: executive power sharing or government by a grand coalition, a high degree of segmental autonomy, proportionality as the standard of political representation, and mutual veto rights. ${ }^{4}$

Lijphart adopted the term consociational democracy to explain political stability in the culturally fragmented societies of Austria, Switzerland, the Netherlands and Belgium. Consociational model was also applied in Lebanon 1943-1975, Cyprus 1960-1963, Malaysia 1955-1969, Surinam 1954-1975 and Colombia 1958-1974.3 More recent studies focussed on Northern Ireland (1973/74 and since 1998), South Tyrol (since 1972), Bosnia-Herzegovina (since 1995), India (since 1947) and South Africa (since 1994). Lijphart and others refined the concept and concentrated on the factors conducive to the advent of consociational democracy, thereby enhancing not only the explanatory, but also the normative power of the theory. ${ }^{5}$
Lijphart's consociational democracies based on four organizational principles.

\section{1) Grand Coalition}

According to grand coalition, the political leaders of all important segments or parties of the plural society cooperate in a grand coalition to govern the political system of a country.

\section{2) Autonomy or self-government}

Each enjoys some distinct measure of autonomy, particularly self-government in matters of cultural concern.

\section{3) Proportionality}

Each is represented proportionally in key public institutions and is a proportional

Beneficiary of public resources and expenditures.

\section{4) Veto-rights}

Each is able to prevent changes that adversely affect their vital interests.

These arrangements are thought to have several benefits over majority rule, generating gentle governance with more inclusive processes of decision-making, more democratic policy outcomes, and better economic development. However, the potential advantages of power sharing institutions are nowhere more important for good governance; it is suggested, than in segmented societies, which lack cross cutting cleavages. ${ }^{6}$

In the heterogeneous societies, according to Lijphart, Majority rule creates majority dictatorship rather than democracy. Such regimes need a democratic political system that emphasizes on consensus instead of opposition.

\section{Consociationalism in Pakistan: historical overview}

Pakistan after its birth adopts the path of democracy for as future political system, but the military remains the main feature of the Pakistani political system. Due to lack of political vision, absence of constitution until 
1956, Political system did not stand at the pillar of democracy. ${ }^{7}$ In Pakistan, since its creation power sharing arrangement was not long lived. It seems all political governments failed to manage ethnic differences among ethnic groups. The new established governments were not very well renowned to the political process. Pakistan experienced throughout the the period (1947-58) absence of true parliamentary system, absence of periodic general elections, lack of interest aggregation and participation through political parties as the vehicle for mobilization, lack of ethnic accommodation especially both East and West wings. ${ }^{8}$

Mainly, the effective power remains in the hands of military-bureaucracy relationship. ${ }^{9}$ The federal executive of the interim constitution never allowed to extend the executive authority in many provinces, while the segmental autonomy is one of the main feature of consociational democracy. Provincial autonomy was also not extended to the provinces and the segmental cleavage had less effect because the economic activities and needs were more important than any other kind of cleavages. Moreover, the continuous political changes and activities of the ruling regimes reduced the power sharing and grand coalition concepts in Pakistan. In such circumstances we never found the basic characteristics of consociational democracy in Pakistan.

During that political situation Bengalis were not happy even with Objective Resolution in 1949. The Bengalis was adopted agitational tactics when Urdu was declared the national language. Central ruling governments adopted such policies, which widened the gulf between East and West Pakistan. The central government planned those economic strategies that kept East Pakistan under-developed. Such kind of economic policies became a major source to create a sense of insecurity among the Bengalis and consequently, the elections of 1971 remained unable to bridge the gulf between East and West Pakistan. ${ }^{10}$ These elections paved a way for the creation of Bangladesh. We can say that the the principals of consociational democracy, power sharing, proportionality and autonomy totally negated in the case of East Pakistan. If they were adopted above roles then we see the central government should succeeded to adopt consociationalism and the Bengali ethnic issue might be solved to some extent.

The post 1971 political situation was not much different to prior. After the separation of East Pakistan in December 1971, Bhutto took over the office of the President of Pakistan and became the civilian martial law administrator. During his government, nationalism was its high position and he gave to Pakistan its third permanent constitution of 1973. But during his government, the ethnic cleavages occurred in the form of Sindhi language crises. Baloch in Balochistan was not satisfied with the central ruling authority. The Pathans were also dissatisfied with the federal government. Zulfiqar Ali Bhutto had never tried to resolve these ethnic issues by negotiation but with the help of the army. General Zia - ul-Haq played a different game to deal with different ethnic identities. ${ }^{11}$

During the Zia period (1977-88), the normal political process remained suspended. General Zia's era was experienced politico-religious indoctrination, which widened gulf between Sunni and Shia groups. Zia's regime perused supportive policies towards the Baluch and Pushton elites and coercive policies towards Sindhi elites. Under General Muhammad Zia-ul-Haq (1977-88), the so-called Islamization program was enforced in Pakistan. ${ }^{12}$ These Punishments applied to all Pakistanis and did not discriminate among them on the basis of religion.

Benazir Bhutto and Nawaz Sharif governments also remained unable to control the ethnic conflicts and the situation became 
worse with every passing day. We can say the post-Zia period witnessed a number of coalition cabinets. $^{13}$ But, these coalitions or alliances proved themselves short time of period. The spirit of accommodation remained missing in these power sharing arrangements during these governments.

The Musharaf military regime legitimized its rule on appeal to the modernizing and progressive agenda. Musharraf started administrative reforms to devolve power to grass roots level for the purpose of achieving power sharing to some extent. In that reform, these local governments have become tools of the federal government, thus, undermining the federal state structure even further. ${ }^{14}$ Pakistan during his regime plays role as a partner of USA against the terrorism. $\mathrm{He}$ claimed to eradicate extremists, terrorist attacks and suicide bombings. After the Lal Masjid operation (11 July 2007), attacks in NWFP and Balochistan troubled the government.

\section{Contemporary Pakistan}

and obstacles in the way

\section{of establishing Consociational democracy}

Pakistan is a plural society in terms of both ethnicity and religion. Its record of political supervision of pluralism has been at best miscellaneous and in general far from adequate. The efforts of the ruling elite to bring about consent on the rules of the game have collapsed several times. Pakistan has suffered through an enduring crisis of civil-military relations, which has adversely affected the agenda of national integration. The military's overt and covert role in the business of the state has cultivated a spirit of intolerance for sub national identities. ${ }^{15}$

Ethnic conflicts and political violence is not a new thing but the contemporary proliferation of conflicts in multiethnic states is such a vital development that requires a careful examination and analysis. The political scientists and constitutional engineers have identified some connections between the political institutions and the proliferation of ethnic mobilization. ${ }^{16}$

The proponents of consociational democracy have suggested it as a viable solution for deeply divided societies to overcome the problem of political instability. Lijphart had advised the constitutional engineers in developing countries to adopt consociational devices to guarantee the political stability. This research examines the establishment and maintenance of consociational democracy in contemporary Pakistani society. Lijphart, who developed and advocated the consociational theory, has recognized certain favorable factors for consociational governance and has assessed the probability of success of consociational democracy in various cases. Following the Lijphart's approach, this research analyzes the relevancy of consociationalism with the multiethnic society of Pakistan by examining the presence or absence of favorable factors for the consociational democracy.

\section{The four elements of power sharing in contemporary Pakistan}

The multiethnic structure of a state has been regarded as a hindrance to a stable democracy. So, the political scientists have been remained busy in inquiring a democratic model that can ensure political stability in diverse societies. Power sharing has been considered as a prominent approach by political scientists to guarantee political stability in such societies. McGarry \& O'Leary, the two most prominent members of consociational school of thought at the moment, have suggested that Pakistan "will need to adopt and maintain consociational governance at federal centre to "practice democracy". ${ }^{17}$ Subsequently, Adeney has asserted that Pakistani federation's incapacity to manage ethnic diversity is the consequence of its nonconsociational features. In Pakistan as we already analysis, democracy was 
not so smooth and persistent in its functioning. Pakistani democracy exhibits the characteristics of consociational democracy.

For the political incorporation and accommodation for marginalized groups, consociationalism suggests grand coalition cabinets to ensure power sharing in multiethnic societies. Consociations can be both democratic and authoritarian, but the complete consociational democracies respect four organizational principles.

\section{1) Grand Coalition}

According to the Lijphart, the primary principal of consociational democracy is that the political leaders of all ethnic groups of the plural society cooperation in a grand coalition to govern the country. Government by great coalition can take many different forms. The model is an inclusive cabinet coalition of ethnic, linguistic, or religious parties, as in the Austrian, Malaysian and South Africa power sharing system, but there are many other possibilities. ${ }^{18}$ During the general election of 2008, the PPP curbs great sympathy due to the assassination of Benazir Bhutto and Zardari hold the office of president. The Zardari regime seems more democratic in nature and formed a coalition government. The leaders of the key political parties, the Pakistan People's Party (PPP) and the Pakistan Muslim LeagueNawaz (PML-N), which came together to form a coalition government have not succeeded. But this coalition government no long lasting and ended on 25 August 2008. That coalition government ended up on the issue of judges. ${ }^{19}$

The expelling of the PPP $\square \mathrm{s}$ ministers from the Punjab Government in 2011 meant to create serious problems to the promotion of democracy and politics of reconciliation in the country. Due to the that circumstance, PPP was forced to seek alliance with the MQM.

In April 2011, Pakistan Muslim LeagueQuaid (PML-Q) join the PPP-led coalition government in the Centre. According to the central government, then both parties aimed at political re-alignment and strengthening reconciliation to address various issues confronting the country in an atmosphere of political stability, mutual tolerance and accommodation. ${ }^{20}$

They also agreed to work together and cooperate for strengthening democracy, ensuring electoral reforms, reforms in FATA, creation of new provinces specially in Southern Punjab (Seraiki) and Hazara. But in reality, that coalition government could not the guarantee of stable democracy in Pakistan.

In contemporary Pakistan, the leadership always plays a central role in decision making process of making and breakup of an alliance. However, the failure of party rules and regulation, and failure of committees and agreements are responsible for the broken of various coalitions in Pakistan.

The above analysis of the recent governmental political system of Pakistan never allows to flourish democracy in Pakistan, so we can say that in these circumstances the nourishment of consociational democracy is quite difficult because the central government not ready to adopt the policy of accommodation and reconciliation with their allies such in case of PPP-PML-N coalition government abolished on the issues of judges.

Pakistan found active in forming a coalition government to maintain their power but these coalitions destined to break down frequently. Because these coalitions made to fulfill their personal interest that's why their length is determined just according to their interest.

\section{Autonomy or self-government}

Cultural autonomy of religious and linguistic groups has taken three forms a power sharing democracies: 
(1) Federal arrangements in which state and linguistic boundaries largely coincide, thus provide a high degree of linguistic autonomy as in Switzerland, Belgium, and Czecho-Slovakia.

(2) The right of religious and linguistic minorities to establish and administer their own autonomous schools, fully supported by public funds as in Belgium, and the Netherlands.

(3) Separate personal laws concerning marriage, divorce, custody and adoption of children and inheritance for religious minorities as Lebanon and Cyprus. ${ }^{21}$

Pakistan is a multiethnic state. It is composed of four provinces, the federal capital, and federally administered tribal areas (FATA). Each of its provinces is a homeland of more than one ethno linguistic groups. Punjabis and Siraikis are based in Punjab. Sindh is the homeland of Sindhis and Mohajirs, an Urdu speaking community that migrated from India in 1947 and mostly settled in urban centers of Sindh. Pashtuns and Hindkospeaking community are residents of Khyber Pakhtunkhwa.

If in a country, people's rights are denied at the very grassroots level, their political participation is ignored by the central government. All these things leads to deprivation and alienation at economic and social level. The ethnic diversity of Pakistan could lead the country towards more disintegration like the creation of Bangladesh in 1971, as the movements for new provinces are gaining momentum, with the Pakistan People's Party (PPP) in forefront in favor of carving out the Saraiki province of Punjab. For the first time in Pakistan's history, maximum autonomy and resources have been given to the provinces under the 18th Amendment and new National Finance Commission (NFC) award, which has weakened the grasp of the federal government on many important issues. ${ }^{22}$ The PPP which encouraged the demand for a separate Saraiki province and gave support to the Pakistan Muslim League (Quaid)
PML-Q demand for Hazara province only just for political interests, ignoring the consequences of an ethnic division of Pakistan.

President Zardari achieved two political objectives by renaming NWFP; he created a space that is more political for his party in Khyber Pakhtunkhwa and weakened the Pakistan Muslim League Nawaz (PML-N) in Hazara division the PML-N's monopoly as the Hindko-speaking residents of Hazara were strongly opposed to the Pakhtukhwa name.

The Baloch identity contention has been the most vocal and violent. The movers for an independent Balochistan has been going on since 1947 as a majority of the tribal leaders were against joining Pakistan. Pakistani State has used military force on three occasions 1962, 1973-7, and 2004 to suppress its armed and violent expression but the insurgency gained momentum after the killing of Baloch nationalist leader Nawab Abkbar Bugti during President Musharraf's regime in 2006. ${ }^{23}$

The democratic government declared peace and reconciliation in Balochistan as one of its primary objectives, and promised to focus on resolving the Balochistan problem through negotiations. The present government has announced a development and reform package, Aghaz-e-Haqooq-e-Balochistan, (beginning of rights of Balochistan) to win back the insurgents, but they rejected the package and called for an independent state. Recently, the Awami National Party (ANP) has demanded a separate province for Pashtuns in Balochistan in the name of Southern Pakhtunkhwa. ${ }^{24}$

Sindhi identity that gives its name to the province of Sindh faces a weird problem. Sindhi ethnic movement is the most aware and vocal of the different identities in the post Bangladesh (1971) Pakistan. They face the challenge of becoming a minority in their own province. Sindh's largest towns like Karachi and Hyderabad 
are predominantly non Sindhi. The Muhajir Quami Movement has become a force to reckon with in the urban centers of Karachi. The civil and military establishments decided to divide the immigrants in the 1990s and Karachi was turned into the city of weapons. ${ }^{25}$

Nowadays the city has been changed into a battlefield, and almost 800 people have been killed in various incidents of target killing and violence since January 2011. During the recent bloodshed, the demand for a separate province for Urdu speaking people in Karachi re-emerged. If Punjab and Khyber Pakhtunkhwa were divided on ethnic basis, then the Urdu speaking people could also demand their separate province.

Many people contest the status of Saraiki as a separate language. The Saraiki issue was stirred during 2009 due to economic discrimination against their rightful share in social development. If the issue of Saraiki province is not tackled carefully by the government, the demand for new provinces on an ethnic basis could emerge from other provinces as well.

Prrovincial autonomy, a long standing demand of the four provinces of Pakistan, has received a momentum from the $18^{\text {th }}$ Amendment. Inshort after passing $18^{\text {th }}$ amendment, when NWFP was renamed as Kyber-Pakhtunkhwa, people demand Hazara, Bahawapur, Saraiki as separet provinces. Even that the ANP (Awami National Party) demand for a separat Southern Kyber-Pakhtunkhwa for the Pakhtuns living in Baluchistan.

Segmental autonomy is actually demanded in the result of segmental cleavages. Pakistan is a deeply divided society, it is divided on the basis of sects, languages and geographical region and each segment demanded its autonomy.

\section{Proportionality}

In accordance with the principal of proportionality, the normal electoral system in power sharing democracies is proportional representation. The principle of proportionality is closely interconnected with the grand coalition principle. Proportionality serves two important functions. First, it is a method of allocating civil service appointments and scarce financial resources in the form of government subsidies among the different segments. The other method is to delegate the most difficult and fateful decisions to the top leaders of the segments. The proportionality principles is an important tool in this process.

The recent government is following the pattern of reconciliation and working for the restoration of the democracy and to establish a stable democracy in Pakistan with the coalition of elites of all segments. For Baluchistan the reform package "Aghaz-e-Haqooq-e-Balochistan" (Beginning of the Rights of Balochistan) was announced on 24 November 2009. This reform package based on government goodwill to resolve those issues i.e. Baloch Nationalists mainly blamed on central government. But this reform package failed to accommodate the Baloch ethnic group. ${ }^{26}$

The recent government issued an autonomy package for Northern Areas in September 2009. It re-named the area Gilgit-Baltistan, and provided it a province-like status. However, the people demand full provincial autonomy for their province, in that case it will be Shia dominated province. In past the Gigit-Baltistan undergone the process of Sunism. But that area is disputed over the issue of Jammu \& Kashmir between India and Pakistan since partition. And after this 2009 package it is widely believed that Pakistan tried to integrate the disputed area in administrative system.

The $7^{\text {th }}$ NFC Award signed on 30 December 2009 and came into force $1^{\text {st }}$ July 2010 . The NFC were to be convened every five years. According to the constitution, NFC means to allocate those 
funds which collected by the federation among provinces. But these grants made as part of the NFC reward do not produce fical efficiency in the country. The $18^{\text {th }}$ amendment was passed several months after the $17^{\text {th }}$ NFC Award was finalized, but since the $18^{\text {th }}$ amendment has transferred several jurisdictional areas to the provinces, the provinces are demanding that their share of revenue collected by the central governmentbe increased.

The famous18th Amendment passed in April 2010 was the most inclusive reform package from the recent government. ${ }^{27}$ The 18th amendment abolished the 17th amendment that had given enormous authority to the president. The $18^{\text {th }}$ amendment no doubt will have great impact on the way in which country is governed and its economy is managed. Due to this amendment, the provinces received additional powers as a result of the abolition of the concurrent list of the 1973 constitution. Through this amendment large amount of economic authority transferring to the provinces. But the provinces remain dependent on the central government for funds. So we can say that the promised of autonomy remain uncertain because the provinces still unable to financing their economic activities. Problems of different segmental autonomy only can be resolved by the proportional representation in governmental machinery according to their population to accommodate their interest.

\section{Minorities Veto}

Minorities veto is the most important method of consociational democracy. The minority veto in power sharing democracies usually consist of merely an informal understanding that minorities can effectively protect their autonomy by blocking any attempt to eliminate or reduce it. A minority veto only such a veto can give each segment a complete guarantee of political protection. According to Lijphart, grand coalition not offering absolute protection.

Pakistan is a country with almost 98 percent of Muslims resides there and the rest was consisted of the minorities: Hindus, Christians, Ahmadis, and several miniscule groups such as Parsis, Buddhists and Sikhs together accounting for 3.54 per cent of the population. The Muslim majority also subdivided into two main sects Sunni (80\%) and Shi'ah (20\%) and Sunni are further divided mainly amongst Barelvis, Deobandis, and Ahl-iHadith.

Some parallel domestic dynamics also contributed to the rise of sectarian violence. the main reasons of violence between Sunni and Shi'ah, the policy of Islamization undertaken by General Zia-Ul-Haq, which alienated the Shi'ah community. The coming out of sectarian politics within religious parties and militant organization must also be pointed out as it radicalized the tensions between Shi'ah and Sunnis.

After $9 / 11$, one of the most dangerous situation of the Shi'ah community of the Federelly Administered Tribal Areas (FATA), where many Shi'ah killing by Taliban and Al-Qaida. Even that General Pervaiz Musharraf banned both Sunni and Shi'ah sectarian militant groups. But after Musharraf's departure, some have expressaed fears of a reemergence of anti-Shi'ah militant groups in 2008 and 2009. Paakistan can no longer afford to ignor the growing potential sectarian violence that destabilized it gradually.

Pakistan is a democratic country but its legal framework is close to a theocratic state. The political structure of Pakistan based on the parliamentary democracy but it is known as an Islamic country and Islam has been declared as the state religion.

The constitution of Pakistan does not explicitly recognize the national and ethnic minorities, just accept their rights to some extent. The constitution guarantees the right to freedom 
of belief; every religious group has the right to maintain its religious institutions. However in the constitution of Pakistan, some provisions clearly treat Muslim citizens preferentially, the others just ignore the fact that Pakistan is a multi religious society. There are a number of policies concerning such as a syllabus for education institutions, government controlled media, admissions and filling vacancies that are based on biases for religious minorities. The personal laws of minorities need thorough review, as they are a source of human rights abuses. ${ }^{28}$

Recent killings of minorities in Pakistan have created new attention on the issues of minorities in a country that is generally perceived to be a homogeneous Muslims nation. In country besides ethnic regional groups like Baloch, Muhajir, Punjabi, Pushtuns and Sindhis, there are numerous religious group including Christians, Budhists, Sikhs and Hindus together with other smaller Islamic groups.

The political history of Pakistan mostly influenced by military rule. The political use of religion by all governments poses several challenges for minorities in Pakistan. Non-Muslim minorities in Pakistan are subject to harsh religious laws and faced discrimination. espacially during Mussharraf regime, military decision to joined US-led coalition against terrorism has provoked resentment and an internal backlash by extremist groups with renewed violence against minorities. According to minorities the amendments in the constitution and Blasphemy law abolished their rights as citizens.

The recent government felicitating the minorities in Pakistan. President Asif Ali Zardari has said that the Pakistan People's Party (PPP) will continue to uphold the right of Christians and all minorities, to be treated as equal citizens of the state. ${ }^{29}$

Prime Minister Yousaf Raza Gilani said the constitution of Pakistan gave individuals a right to practice their religion freely and shares economic opportunities for their empowerment. He said he had directed the Capital Development Authority (CDA) to expedite the process of up-gradation and development of katchi abadies, particularly Christian dwellings in Islamabad.

The case of Aasia Bibi shows many inconsistencies in the blasphemy laws of the country. Because religious minorities claimed that, Pakistan's law against blaspheming Islam carries the death penalty while no one has ever been sent to the gallows for the crime, they also argue the law is used to exploit others out of personal enmity or business disputes.

In the aftermath of two high-profile murders, namely Governor Taseer's and Minister Shabaz Bhatti declaring all those who seek reform as blasphemers, (thus making them targets for extra-judicial killings) provided a turning point for Pakistan's mainstream discourse on religious extremism to review its retreat. It also provided a dangerous example of a slide into killings sanctioned by religion and state inaction.

\section{Conclusion}

According to our point of view, ethnic conflicts are inevitable in all ethnically divided countries. The ethnic conflicts in all South Asian countries are not exceptional. Political institutions that are sufficiently well adapted to the country's ethnic cleavages may accommodate and mitigate ethnic interest conflicts.

After a short review of the theoretical framework of the plural society and consociational democracy concept, we started to analyze the socio-cultural and political structure of contemporary Pakistan. We concluded,the consociational character of Pakistan's democratic system is difficult to elaborate. It is not consistent and prolong. Military takeovers and concentration of power in one hand made democracy difficult to exercise 
democratic pattern within consociational democracy. Regional ethnicity, General conflict over resource allocation, General accusations of Punjabilization, and proportionality lack of having resource implications are the main issues for non consociationalism in Pakistan.

Despite of all above inconsistencies, the current regime is more consociational then other regions because this government aims to establish a coalition between the leaders of different segments and also tried to compensate their deprivations continued from the previous governments. But there is still a long way to go. The recent government of Pakistan is trying to to establish a stable democracy which is somewhat may lead to consociational democracy. In short we can say that, if democracy takes its roots in Pakistan then consociational democracy can effectively work to run the machinery of government.

\section{Recommendation}

Consociational democracy has a certain limitation and difficulties in order to its implementation in plural societies. The diverse nature of the plural societies made it more difficult to establish a stable consociational democracy.

1. To attain stable democracy first of all, we have to understand the nature of the plural societies and understand the democractic pattern of the state. It is also needed to understand the diversity among different segments and their causes as well to resolve them. This will help to establish trust on the institutions that will lead to stable democracy.
2. Independent commissions for racial, religious, should be set up, to receive and investigate complaints, to offer advice to victims of discrimination and to undertake awareness raising activities to promote the principles of non discrimination and understanding between different segments.

3. The government of Pakistan has initiated a series of steps that could potentially strengthen consociational democracy. These include progress in talks with nationalist parties; land distribution programs and allowances to political parties in disputed areas. These measures should be boosted, while direct channels, such as local governments and devolution programs.

4. Greater provincial participation and inclusion should be encouraged by providing platforms through which grievances can be aired and addressed.

5. The authorities should ensure that religious and other minorities can participate in decision making, including reserved seats in government and Parliament, consultative bodies at the national and local level covering matters of concern to minorities, and forms of cultural or territorial autonomy.

6. The power should not be concentrated in the solid majority, the power sharing system must be flexible that can be molded according to the circumstances. Otherwise concentration of power in one person is not good for consociational democracy.

\footnotetext{
Shahzad, Aisha. (2007). The Issues of Ethnicity in Pakistan (1972-85). Islamabad: D.G. Administration, HEC. Pp.11-45.

2 Munir, Shafqat. (2010). Pakistan's Transition to Democracy: A Synthesis of Studies on Democracy and Electioneering. Retrieved May 11, 2011, from http://jdhr.org/publications/books/Transition\%20to\%20Democracy.pdf.

3 Ibid.

4 Lijphart, Arend. (1977). Democracy in Plural Societies: A Comparative Exploration. London: Yale University Press. pp. 2-28.
} 
5 McGarry, John., \& Leary, Brendan, O. (2006). Consociational Theory, Norther Ireland's Conflict, and its Agreement Part 1: What Consociationalists Can Learn from Northern Ireland. Government \& Opposition. Retrieved May 1, 2011, from www.polisci.upenn.edu/.../Brendan\%20O'Leary/publications/.../..PDF/Adobe Acrobat.

ibid.

Ziring, Lawrence. (2007). Pakistan in twentieth century: A political history. Karachi: Oxford University Press. P. 45-67.

Pattanaik, Smruti S. (2004). Pakistan's Sustainable Democracy: Army as the Political Architect. Strategic Analysis, 28(2). Retrieved April 21, 2011, from strategicanalysis_smruti_0604.pdf.

$9 \quad$ Siddiqa, Ayesha. (2007). Military Inc. Inside Pakitan's Military Economic. New York: Oxford University Press. Pp. 5880.

10 Noor, A., Hussain. (1998). Fifty Years of Pakistan Army 1947-1997. Rawalpindi: ISPR Publication. Pp.20-88.

11 Talbot, I. (2005). Pakistan; A Modern History. London: Macmillan. Pp.48-89.

12 Waseem, Muhammad. (2000). Pakistan Martial Law 1977- 1985. Lahore: Vanguard Books Ltd. Pp.78-89.

Ziring, Lawrence. (2007). Op.cit.

14 Mohmand, S., K. (2008). Local Government Reforms In Pakistan: Strenthening Social Capital or Rolling Back the State? ( Gellner, D., N. \& Hachhethu, K., ED.). New Delhi: Sage Publications Pvt Ltd. Pp. 380-411.

15 Siddiqa, Ayesha. (2007). Op.cit.

16 Khan, M, A. (2005). We've Learnt Nothing from History. New York: Oxford University Press. P. 247.

17 Adeney, K. 2007. Federalism and Ethnic Conflict Regulation in India and Pakistan. Retrieved May 11, 2011, from PDF/ Adobe Acrobat.

18 Lijphart, Arend. (1977). Op.cit.

19 Kronstadt, Alan, K. (2010). Pakistan: Key Current Issues and Developments. Retrieved May 11, 2011, from www.crs.gov. pdf.

20 O'Connor, T. (2011). Regimes Elites, and Parties, MegaLinks in Criminal Justice. Retrieved February 1, 2012 from http:// www.drtomoconnor.com/4090/4090lect06.htm.

21 McGarry, John., \& Leary, Brendan, O. (2006). Op.cit.

22 Burki, Shahid, Javed. (2010). The 18th Amendment: Pakistan's Constitution Redesigned. Retrieved February 1, 2012 from www.isn.ethz.ch/isn/Digital-Library/Publications.pdf.

23 Majeed, Gulshan. (2010). Ethnicity and Ethnic Conflict in Pakistan. Journal of Political Studies, 1(2). Retrieved February 1, 2012 from pu.edu.pk/images/journal/pols/Currentissue-pdf/Gulshan3.pdf.

24 Sumbal, Ayub, Malik. (2011). Ethnic Division of Pakistan: More Dhaka-like Debacles in the Offing. American Daily Herald. Retrieved December 22, 2011, from http://www.americandailyherald.com.

25 Behuria, Ashok, K. (2005). Myth of the Monolith: The Challenge of Diversity in Pakistan. Retrieved December 22, 2011, from http://idsa.in/system/files/strategicanalysis_akbehuria_0305_0.pdf.

26 Muhammad, Waseem. (2010). Federalism in Pakistan. Retrieved December 22, 2011, from www.forumfed.org/pubs/Waseem-Fed-Overview.pdf.

27 Ibid.

28 A Jinnah Institute Research Report. (2011). A Question of Faith: A Report on the Status of the Minorities in Pakistan. Retrieved December 22, 2011, from http://www.sacw.net/article2126.html PDF/Adobe Acrobat.

29 PPP committed to uphold rights of minorities: Zardari. (Sunday, December 25, 2011). Daily Times Pakistan. Retrieved December 22, 2011, from www.dailytimes.com.pk

\title{
Проблемы и трудности многообразия
}

\section{в современном Пакистане:}

является ли консоциональная демократия

жизнеспособным решением?

\author{
Самина Нур \\ Исламский университет Бахавалпура \\ Пакистан
}

В настоящее время Пакистан столкнулся со многими проблемами и трудностями, которые представляют угрозу стабильности и демократизачии, одна из этих проблем - этническое разнообразие. Данная статья посвящена нашему исследованию той угрозы, которую представляет этническое разнообразие для истоков демократии в современном Пакистане. Нужно ли Пакистану придерживаться консоииональной теории, чтобы реализовывать 
демократию? Если да, то какие консоииональные меры необходимо принять по отночению к этническим меньшинствам? В данной статье авторы пытаются ответить на эти вопросы, принимая во внимание этнический состав Пакистана, роль и сильные стороны Пакистанской федерации по отнотению к управлению этническим разнообразием, а также меры по разделению власти, представленные в консочиональной демократии Лейпхарта.

Ключевые слова: консоциональная демократия, разделение власти, пропорииональное представление этнических групп, провинииальная автономия.

Научная специальность: 23.00.00 - политология. 